\title{
PRODUKSI CAIRAN DETERJEN TRADISIONAL RAMAH LINGKUNGAN DARI BIJI LAREK DALAM UPAYA MENJAGA EKOSISTEM SUNGAI
}

\author{
Zouhrotun Diniah \\ zouhrotundiniah2@gmail.com \\ Mahasiswa Fakultas Agama Islam Universitas Ibn Khaldun
}

\begin{abstract}
ABSTRAK
Sungai merupakan wadah atau jaringan pengaliran air dari hulu ke hilir. Artinya sungai ini tidak dapat dipisahkan dengan kehidupan masyarakat disekelilingnya. Sungai itu sendiri kualitasnya dipengaruhi aktifitas dan prilaku penghuninya. Deterjen merupakan suatu bahan pembersih yang dibentuk dari bahan kimia sintesis dengan komponen utama surfaktan. jika limbah deterjen dengan jumlah tertentu dapat mencemari lingkungan, khususnya sungai, karena sifat deterjen ketika di dalam air dapat menimbulkan banyak busa, akibatnya mengganggu difungsi oksigen dari udara kedalam perairan, secara tidak lagsung terganggunya difungsi oksigen dapat berpengaruh terhadap kehidupan organisme perairan, Dengan melihat beberapa kerugian akibat limbah detrejen dan manfaat biji buah larek serta ketidak tahuan generasi sekarang dan perubahan gaya hidup yang serba praktis penulis manfaatkan untuk membuat suatu produk deterjen tradisional yang ramah lingkungan dari biji larek, yang dikemas dengan kemasan menarik dan kekinia.
\end{abstract}

Kata Kunci: Deterjen, Limbah, Sungai.

\section{PENDAHULUAN}

\section{Latar Belakang}

Sempat terfikir tidak, di zaman sekarang ini kita sulit untuk menemukan sungai bersih dengan ekosistem air yang berfungsi dengan baik di Indonesia ini? Rasanya sangat sulit. Dari pedesaan hingga perkotaan, hampir terkontaminasi dengan deterjen.

Sungai merupakan wadah atau jaringan pengaliran air dari hulu ke hilir. Menurut Wiwoho "sungai merupakan tempat berkumpulnya air di lingkungan sekitarnya, yang mengalir menuju tempat yang lebih rendah. Daerah sekitar sungai yang mensuplai air ke sungai dikenal dengan daerah tangkapan air atau daerah penyangga. Kondisi suplai air dari daerah penyangga dipengaruhi aktifitas dan prilaku penghuninya."

Artinya sungai ini tidak dapat dipisahkan dengan kehidupan masyarakat disekelilingnya. Sungai itu sendiri kualitasnya dipengaruhi aktifitas dan prilaku penghuninya. Aktifitas dan prilaku penghuni menggunakan deterjen bertipe keras disekelilingnya mengakibatkan tecemarnya sungai,

Deterjen merupakan suatu bahan pembersih yang dibentuk dari bahan kimia sintesis dengan komponen utama surfaktan. supaya deterjen terlihat baik sehingga dapat menarik konsumen 
komponen utama membutuhkan bahan pembangun dan bahan aktif, bahan pembangun umumnya berasal dari polisofat yang berperan untuk menghasilkan kerja surfaktan, bahan tambahan tersebut bisa berupa sodium silikat, sodium perborat, karboksilmetil selulosa, dan lainnya. Belum lagi bahan tambahan untuk memberikan aroma yang beranekaragam.

Sehingga, jika limbah deterjen dengan jumlah tertentu dapat mencemari lingkungan, khususnya sungai, karena sifat deterjen ketika di dalam air dapat menimbulkan banyak busa, akibatnya mengganggu difungsi oksigen dari udara kedalam perairan, secara tidak lagsung terganggunya difungsi oksigen dapat berpengaruh terhadap kehidupan organisme perairan, fungsi dan kualitas sungai akan hilang dan jika air yang tercemar terserap tanah kesuburan tanah juga akan hilang. Busa tersebut juga bisa menghasilkan bau tak sedap yang berasal dari proses penguraian bahan organik lanjutan dari bakteri anaerob.

Untuk mengatasi pencemaran air akibat limbah deterjen ini kita bisa melakukan beberapa upaya untuk menguranginya diantaranya, menanam tanaman air yang menyerap zat pencemar, eceng gondok, bunga ungu, lidi air, melati air. Membuat penampungan limbah detergen, dan yang paling penting adalah melakukan pemilihan deterjen atau belarih deterjen dengan bahan pencuci alami ramah lingkungan seperti buah larek.

Buah larek atau sering disebut dengan "klerek" adalah bahan pembersih alami yang berasal dari pohon larek (Sapinus mukorossi). Larek banyak tumbuh di Indonesia. Sehingga dijadikan deterjen tradisional oleh nenek moyang kita untuk mencuci kain batik.
Buah yang memiliki nama latin latin Sapindus rarak De Candole ini memang dikenal karena manfaat bijinya untuk deterjen tradisional ramah lingkungan. Kandungan saponin yang berfungsi sebagaigai surfaktan alami. Jika dicampur degan air dan dikocok, akan menimbulkan busa. Kelebihan lainnya busa tersebut tidak meninggalkan zat residu kimia, tidak berbau dan tidak merusak kain. Selain bijinya yang memiliki manfaat, kulit buah larek dapat juga dimanfaatkan untuk mengurangi jerawat pada wajah dan luka.

Dengan melihat beberapa kerugian akibat limbah detrejen dan manfaat biji buah larek serta ketidak tahuan generasi sekarang dan perubahan gaya hidup yang serba praktis penulis manfaatkan untuk membuat suatu produk deterjen tradisional yang ramah lingkungan dari biji larek, yang dikemas dengan kemasan menarik dan kekinia. Selain itu dapat meningkatkan nilai jual biji larek menjadi suatu produk yang bernilai dan ramah lingkungan, selain itu melestarikan budaya Indonesia dan memanfaatkan sumber daya.

\section{Tujuan Penelitian}

Penelitian ini bertujuan untuk memberikan solusi kepada pemerintah khususnya dan kepada masyarakat umumnya untu beralih menggunakan deterjen yang ramah lingkungan, sehingga perlahan dapat memperbaiki ekosistem sungai dan lingkungan sekitar serta untuk mengasah kreatifitas penulis dalam memberikan solusi terhadap masalah di dalam masyarakat sebagai bentuk pengabdian.

\section{Manfaat Penelitian}

Penelitian ini bermanfaat untuk mengembalikan fungsi sungai dengan 
beralih konsumsi deterjen keras ke deterjen

tradisional ramah lingkungan.

\section{GAMBARAN UMUM RENCANA USAHA}

Menjelang akan dilaksanakannya Asian Games dan Asian Para Games 2018 Kali Sentiong atau sering disebut Kali Item ini sudah menjadi perhatian khusus pemprov, karena letaknya berdekatan dengan wisma atlit.

Kali sentiong terkenal dengan kumuh dan bau yang tidak sedap, pemprov berupaya semaksimal mungkin untuk mengurangi bau tak sedap tersebut. Upaya yang dilakukan dari membersikan sampahsampah sampai dengan memasang waring.

Namun beberapa hari kemarin ini Kali Sentiong menjadi menjadi perhatian Anies Rasyid Baswedan sebagai Gubenernur DKI Jakarta. Air dari Danau Sunter dipompa dan masuk ke Kali sentiong menghasilkan banyak buih putih.

Menurut Anies busa tersebut muncul akibat limbah rumahtangga, khususnya deterjen, beliau mengira deterjen yang dikosumsi masyarakat merupakan jenis deterjen yang bertipe keras. Pernyataan tersebut dibenarkan oleh kepala dinas Lingkungan Hidup DKI Jakarta Isnawa

\section{METODE PALAKSANAAN}

Di Indonesia, penggunaan deterjen berbahan kimia lebih mendominasi dibandingkan deterjen alami, padahal ancaman bahaya penggunaan deterjen kimia setiap saat mengintai kita, baik dari segi kesehatan bagi penggunanya maupun lingkungan. Dari permasalahan ini, kami hadir dengan suatu kegiatan usaha yaitu usaha deterjen lerak.

Di kegiatan usaha ini, kami memanfaatan buah lerak sebagai bahan utama pada deterjen karena buah lerak
Adjie, bahwa munculnya busa di kali Sentiong disebabkan oleh limbah deterjen.

Ketika Anies baswedan menghimbau kepada masyarakat untuk beralih ke deterjen soft yang dilansir dalam tirto.id Masyarakat tidak paham dengan jenis-jenis deterjen yang soft. Karena selama ini tidak pernah dilakukan sosialisasi dan kurangya perhatian terhadap kerugian yang disebabkan dari limbah deterjen.

Hal tersebutlah yang nantinya menjadi peluang penulis untuk membangun usaha deterjen tradisional ramah lingkungan.

Nantinya kami tidak berjalan sendiri untuk memberikan solusi ini, tentu kami akan mengajak pemerintah, swasta maupun komunitas yang peduli dengan linggkungan, khususnya komunitas peduli sungai. Untuk ikut serta mensosialisasi terkait dengan bahaya limbah deterjen dan manfaat lerak yang belum banyak masyarakat tau. Hal tersebut lah yang membuat penulis yakin untuk membuat produk tersebut.

(sapindus rarak) merupakan buah yang mengandung saponin sehingga sangat berpotensi sebagai alternatif deterjen yang ramah lingkungan dan aman bagi manusia.

Pohon lerak banyak ditemui di indonesiaterutama di daerah sumatera dan jawa, sertasudah banyak yang membudidayakanpohon lerak, sehingga keterbatasan akan sumber daya alam tidak perlu dihiraukan. Selain itu, masih sedikit masyarakat indonesia yang mengelolah buah lerak. 
Keunggulan dari deterjen lerak kami dapat menyaingi deterjen kimia yang banyak digunakan masyarakat indonesia yaitu selain membasmi kuman-kuman dan bakteri-bakteri yang merugikan pada pakaian dan aman bagi pengguna serta lingkungan, deterjen lerak juga dapat mempertahankan warna pakaian, memperkuat serat-serat kain pada pakaian, dan juga menghemat penggunaan air.

\section{Proses Produksi}

A. Cara Pembuatan

1. Merebus biji lerak selama satu dua jam.

2. Setelah itu, biji lerak akan menghasilkan semacam minyak. Setelah mendapatkan tingkat kekentalan yang diinginkan, kemudian menyaring air rebusan biji lerak tadi.

3. Menambahkan pewangi sesuai dengan jumlah air rebusan leraknya, sambil mengaduknya.

4. Kemudian mendiamkan hasilnya sampai dingin.

5. Mengemasnya didalam botol sesuai ukurannya

\section{Pengemasan}

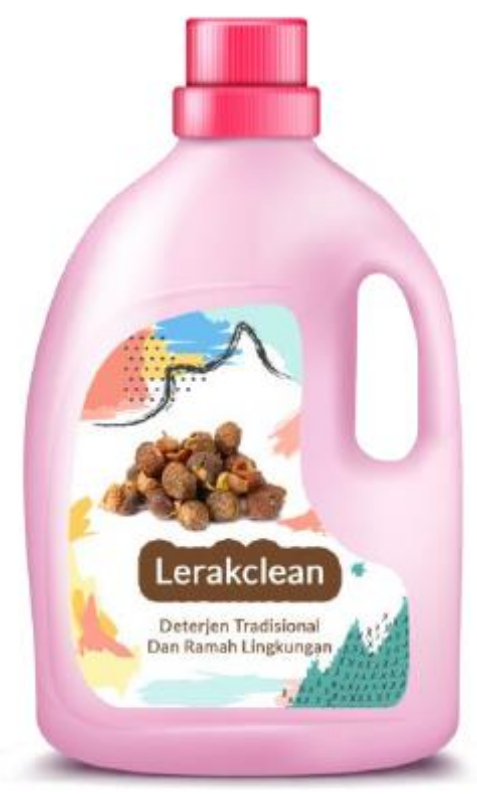

Gambar 1.1

\section{Keterangan Kemasan:}

Botol ini berukuran 1L, kami mengambil warna pink karena target konsumen kami adalah kalangan perempuan. Dan untuk menarik perhatian konsumen, kami berusaha mengemas dengan desain yang moderen. Keunggulan dari botol ini adalah bisa dimanfaatkan untuk jangka waktu yang lama.

\section{Marketing}

Teknik pemasaran produknya dilakukan secara offline dan online. Secara offline, target utama kami yaitu lingkungan . Secara online, kami menggunakan mediamedia sosial. Kami juga ingin meminta pemerintah Propinsi kota Jakarta untuk bekerjasama melakukan literasi atau sosialisasi mengenai produk Deterjen buah lerak ini kepada masyarakat kota Bogor. 
Untuk harga jual deterjen Lerak, harga yang ditawarkan sangat terjangkau dan bisa di akses oleh semua kalangan. Adapun rincian harganya:

Tabel 1 Harga Produk

\begin{tabular}{|c|r|}
\hline Ukuran & Harga \\
\hline Botol 1 L & $\operatorname{Rp~} 30.000$ \\
\hline
\end{tabular}

\section{BIAYA DAN JADWAL KEGIATAN}

Anggaran Biaya (Bahan+Alat)

Tabel 2 Anggaran Biaya

\begin{tabular}{|l|l|c|}
\hline No & \multicolumn{1}{|c|}{ Jenis Pengeluaran } & Biaya \\
\hline 1 & Peralatan & Rp. 2.600 .000 \\
\hline 2 & Bahan Baku & Rp. 9.900 .000 \\
\hline 3 & Transportasi & Rp. 400.000 \\
\hline 4 & Lain-lain & Rp. 600.000 \\
\hline & Total & Rp. 13.500.000 \\
\hline
\end{tabular}

\section{Jadwal Kegiatan}

Tabel 3 Jadwal Kegiatan

\begin{tabular}{|l|l|c|c|}
\hline \multirow{2}{*}{ No } & \multicolumn{1}{|c|}{ Kegiatan } & \multicolumn{2}{c|}{ Bulan Januari } \\
\cline { 3 - 4 } & & $\begin{array}{c}\text { Pekan } \\
\text { ke- 1 }\end{array}$ & $\begin{array}{c}\text { Pekan } \\
\text { ke-2 }\end{array}$ \\
\hline 1 & $\begin{array}{l}\text { Pertemuan dengan Wakil dekan } \\
\text { bidang kemahasiswaan }\end{array}$ & $\checkmark$ & \\
\hline 2 & Pelatihan Pembuatan Proposal PKM & $\checkmark$ & \\
\hline 3 & Pembagian kelompok PKM & & $\checkmark$ \\
\hline 4 & $\begin{array}{l}\text { Persiapan bahan-bahan danalat-alat } \\
\text { pembuatan deterjen lerak }\end{array}$ & & $\checkmark$ \\
\hline 5 & $\begin{array}{l}\text { Percobaan Pembuatan Deterjen Lerak } \\
\text { Cair }\end{array}$ & & $\checkmark$ \\
\hline 6 & Pembuatan Deterjen Lerak Cair & & $\checkmark$ \\
\hline 7 & Pengemasan Produk & & $\checkmark$ \\
\hline 8 & Pengenalan Produk(promosi) & & $\checkmark$ \\
\hline
\end{tabular}

\section{Sumber Dana Kegiatan}

Sumber Dana kegiatan kami peroleh 70\% dari dana PKM dan 30\% dari Proposal dana yang diajukan kepada instansi swasta. 


\section{DAFTAR PUSTAKA}

Sudarno, Dyah Agustiningsih, Setia Budi Sasongko. 2012. Analisis Kualitas

Air dan Strategi Pengendalian Pencemaran Air Sungai Blukar Kabupaten Kendal. Jurnal Presipitasi: Media Komunikasi dan
Pengembangan Teknik Lingkungan: Vol 9, No 2 (2012). Semarang.

Enri Damanhuri, Tri Padmi. 2010. Pengelolaan Sampah, INSTITUT TEKNOLOGI BANDUNG. 